\title{
Morphological characterization of dermal denticles of the Broadnose Sevengill Shark Notorynchus cepedianus (Elasmobranchii: Hexanchidae)
}

\author{
Keny Kanagusuku*1,2, Pablo Dufflocq ${ }^{3}$, Angie Sánchez-Rea ${ }^{1}$, Ana A. Huamantinco ${ }^{4}$, Sergio \\ Ramírez-Amaro ${ }^{5}$
}

Edited by

Juan Carlos Salcedo-Reyes

salcedo.juan@javeriana.edu.co

1. Laboratorio de Investigación, Carrera de Biología Marina, Facultad de Ciencias Veterinarias y Biológicas, Universidad Científica del Sur, Lima, Perú.

2. Programa de Maestría en Ecosistemas y Recursos Acuáticos, Unidad de Posgrado, Facultad de Ciencias Biológicas, Universidad Nacional Mayor de San Marcos, Lima, Perú.

3. Laboratorio de Genética y Biotecnología en Acuicultura,

Universidad de Chile, Santiago de Chile, Chile.

4. Facultad de Ciencias Biológicas, Universidad Nacional Mayor de San Marcos, Lima, Perú.

5. Instituto Español de Oceanografía, Centre Oceanogràfic de les Balears, Moll de Ponent s/n, 07015, Palma, España.

*kkanagusuku@cientifica.edu.pe

Received: 05-08-2020

Accepted: 06-08-2021

Published online: 12-09-2021

Citation: Kanagusuku K, Dufflocq P, Sánchez-Rea A, Huamantinco AA, Ramírez-Amaro S. Morphological characterization of dermal denticles of the Broadnose Sevengill Shark

Notorynchus cepedianus

(Elasmobranchii: Hexanchidae),

Universitas Scientiarum, 26(3): 261-279, 2021.

doi: 10.11144/Javeriana.SC26-3.mcod

Funding: This work was partially funded by Fondo Semilla 2018 (RDN 01-DGIDI- CIENTÍFICA-2018/CRN 002-2018-PRO5) of the Universidad Científica del Sur.

Electronic supplementary material: n.a.

\begin{abstract}
Shark skin is covered by small structures called dermal denticles whose functions are diverse, such as protection, bioluminescence, hydrodynamics, among other functions. These structures have a great variety of shapes and sizes, which can be a useful approach for specimen identification as diagnostic characters between species. The present study aims to describe the dermal denticles morphology of the broadnose seven-gill shark Notorynchus cepedianus, evaluating differences among life-stage (neonate, juvenile and adult), sex and body region (dorsal and ventral). For achieving it, 39 specimens were collected at six landing points along the Peruvian coast. The dermal denticles from two body regions (dorsal and ventral) were photographed, measured (length, width, angle and density), and described using a stereoscope. Dermal denticles measures showed significant morphological differences between body regions as well as stages of development, but not between sexes. The differences are: (1) Crown shape: as the individual grows, it can be seen that the cross shape is losing, (2) Crown cusps: cusps length varied according to the stage of each individual, it was also observed that the lateral cusps are larger in dorsal than ventral region, and (3) Union peduncle - crown: adult specimens and both body regions, the observed union was very dimly and it did not have a defined shape. On the whole, these reported variations in measured traits could be useful as diagnostic characters to identify the stage of development at which the landed and marketed specimens are found.
\end{abstract}

Keywords: description; Peru; placoid scale; taxonomic identification.

\section{Introduction}

Dermal denticles are small structures that cover the body of sharks, which gives them a rough appearance (Compagno et al., 2006; Castro, 2011). Several functions have been attributed to them, including: bioluminescence (Reif, 1985a; Raschi and Tabit, 1992; Dillon et al., 2017; Ferrón et al., 2018), hydrodynamics (Wen et al., 2014; Ankhelyi et al., 2018), protection (Reif, 1978; Raschi and Elsom, 1986; Deynat and Séret, 1996; Compagno et al., 2006; Castro, 2011; Chernova and Vorob'eva, 2010), holding prey against the body during feeding (Southall and Sims, 2003; Ankhelyi et al., 2018), among others. Dermal denticles are originated in the ectoderm tissue (Jolie, 1968; Schaeffer, 1977; Reif, 1982) and covered by strong enamel and dentin-based layer which are fixed to the skin, but being constantly replaced throughout whole shark (Kemp, 1999; Compagno et al., 2006; ACOREMA, 2014). 
The morphology of the dermal denticles would be a simple, fast and inexpensive tool that would help to validate the identification of shark species, especially in ports and landing areas where "trunks" (shark body gutted, finned and headless) (Romero, 2018) are sold and exported as frozen trunks and dry fins (Gonzalez-Pestana et al., 2014). Moreover, specimen misidentification implies mistakes in the obtained biological and fishery information, which can result in inadequate fishery management of this resource.

Furthermore, Notorynchus cepedianus (Peron, 1807) is classified as a "Vulnerable" (VU) species in the Red List of the International Union for the Conservation of Nature (IUCN) (Finucci et al., 2020). In particular, it is one of 31 commercial-relevant species of sharks in Peru (IMARPE, 2015). Despite the importance of sharks in Peru in ecological, fishery social and economic issues, there is still little knowledge about their current conservation status, and studies are scarce and discontinuous over time. The lack of information hinders efforts in population studies and the evaluation of this fishery resource, so more studies of shark species in the country (PRODUCE, 2014) are needed. The present study aims to describe the dermal denticles morphology of the broadnose seven-gill shark $N$. cepedianus, evaluating differences among life-stage (neonate, juvenile and adult), sex and body region (dorsal and ventral).

In the present study, we studied the seven-gilled shark $N$. cepedianus. The species belongs to the Hexanchidae family (Compagno et al., 2006), and its distribution covers the Eastern Pacific from British Columbia, Canada to southern California, Mexico, and from Ecuador to central Chile (Chirichigno and Cornejo, 2001; Compagno et al., 2006; IMARPE, 2015). Besides, $N$. cepedianus is a coastal shark that inhabits the continental shelf up to at least 200 meters and feeds other shark species, bonefish, seals, and carrion (Last and Stevens, 1994; Compagno, 2009). This specie presents relatively large litters, being able to register up to 82 offspring (Ebert, 1996; Compagno, 2009), its birth size is ranged from $40 \mathrm{~cm}$ to $45 \mathrm{~cm}$ of total length (LT), and the maturity age is $4-5$ years $(150 \mathrm{~cm}$ length at first maturity) for males and $11-21$ years $(220 \mathrm{~cm}$ length at first maturity) for females (Van Dykhuizen and Mollet, 1992; Compagno, 2009), respectively.

In particular, it has been studied as shark species identification tool (Tanaka et al., 2002; Valenzuela et al., 2008; Marshall, 2011), community's shark reconstruction, especially based on fossil records (Kriwet and Benton, 2004; Kriwet et al., 2008; Dillon et al., 2017; Ferrón et al., 2019; Rangel et al., 2019) and recognition of morphological patterns associated with their ecology (Reif and Dinkelacker, 1982; Reif, 1982; Muñoz-Chápuli, 1985; Reif, 1985a; Ferrón et al., 2014; Ferón and Botella, 2017; Ferrón et al., 2018; Dillon et al., 2020).

\section{Materials and methods}

\subsection{Sampling and data collection}

A total of 39 specimens of $N$. cepedianus of different sexes (18 males and 21 females) and different life-stages (10 neonates, 22 juveniles and 7 adults) ranging from $328 \mathrm{~mm}$ to $2003 \mathrm{~mm}$ in total length (TL) (Table 1) were collected, since 2006 until 2019 from six landing sites in the northern and central region of Peru: Talara, Santa Rosa, Pacasmayo, Salaverry, Chorrillos and Pucusana (Figure 1). The specimens were identified according to Chirichigno and Vélez (1998) and Romero et al. (2015) procedures. The biological data was recorded (Table 1), and all specimens were photographed. Then, dermal denticles samples of around $1 \mathrm{~cm} \times 1 \mathrm{~cm}$ were obtained from two body regions: (1) dorsal region, in front of the dorsal fin and (2) ventral region, located between the pectoral fins (Figure 2A). Additionally, skin samples were preserved in $1.5 \mathrm{ml}$ microtubes with $96 \%$ ethanol were performed before skin samples examination. Then, skin samples were cleaned 
Table 1. General information Notorynchus cepedianus individuals, reporting sex, mean and standard deviation form total length (TL) in millimeters (mm), life-stage, body region from skin samples and sample number $(n)$.

\begin{tabular}{|c|c|c|c|c|}
\hline Sex & Mean and standard deviation of total length $(\mathrm{mm})$ & Stage & Region & $n$ \\
\hline \multirow{3}{*}{ Female } & $366.00 \pm 32.92$ & Neonate & $\begin{array}{l}\text { Dorsal } \\
\text { Ventral }\end{array}$ & $\begin{array}{l}3 \\
3\end{array}$ \\
\hline & $878.00 \pm 395.17$ & Juvenile & $\begin{array}{l}\text { Dorsal } \\
\text { Ventral }\end{array}$ & $\begin{array}{l}14 \\
14\end{array}$ \\
\hline & $1995 \pm 21$ & Adult & $\begin{array}{l}\text { Dorsal } \\
\text { Ventral }\end{array}$ & $\begin{array}{l}4 \\
4\end{array}$ \\
\hline \multirow{4}{*}{ Male } & $388 \pm 8$ & Neonate & $\begin{array}{l}\text { Dorsal } \\
\text { Ventral }\end{array}$ & $\begin{array}{l}7 \\
7\end{array}$ \\
\hline & $598 \pm 202$ & Juvenile & $\begin{array}{l}\text { Dorsal } \\
\text { Ventral }\end{array}$ & $\begin{array}{l}8 \\
8\end{array}$ \\
\hline & $1933 \pm 95$ & Adult & $\begin{array}{l}\text { Dorsal } \\
\text { Ventral }\end{array}$ & $\begin{array}{l}3 \\
1\end{array}$ \\
\hline & Total & & & 76 \\
\hline
\end{tabular}

and dried for observation conducted in the Research Laboratory of the Universidad Científica del Sur. A Carl ZEISS model Discovery v12 stereoscope with a built-in AxioCam ICc5 camera at $100 \times$ magnification were used to observe and photograph the dermal denticles morphology. The denticles traits measurements (length, width, angle and density) were carried out with the Axio Vision Release 4.8 program.

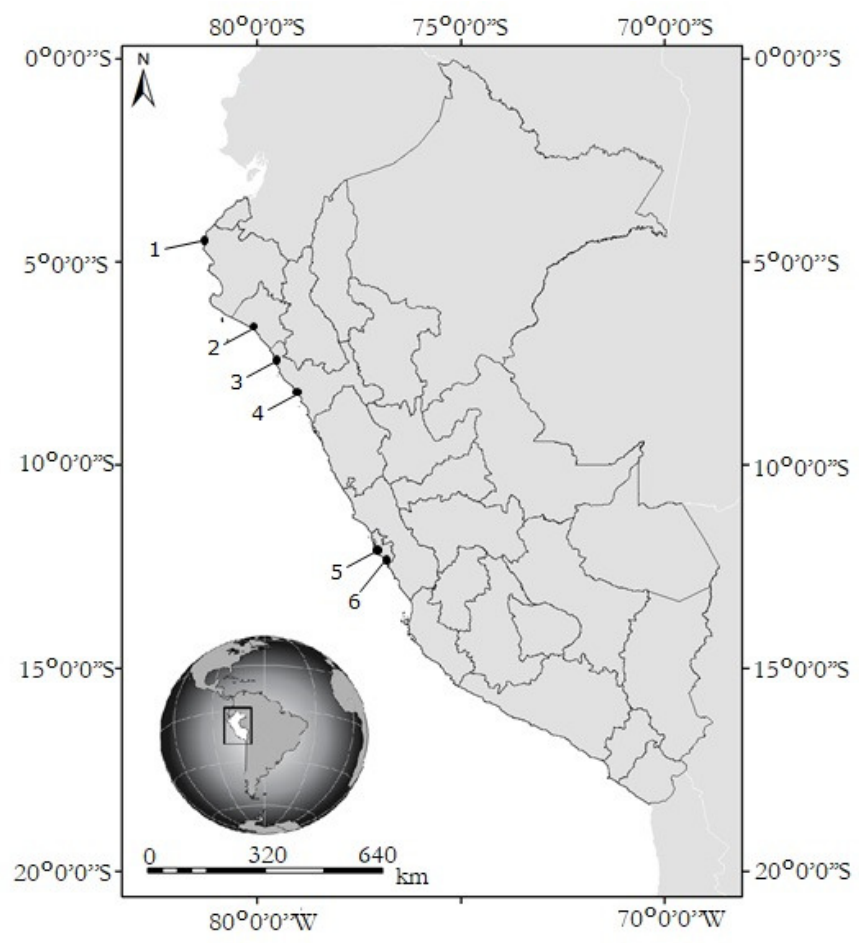

Figure 1. Landing points located on the Peruvian coast where Notorynchus cepedianus specimens were collected: (1) Talara in Piura, (2) Santa Rosa in Lambayeque, (3) Pacasmayo and (4) Salaverry in La Libertad and (5) Chorrillos and (6) Pucusana in Lima. 


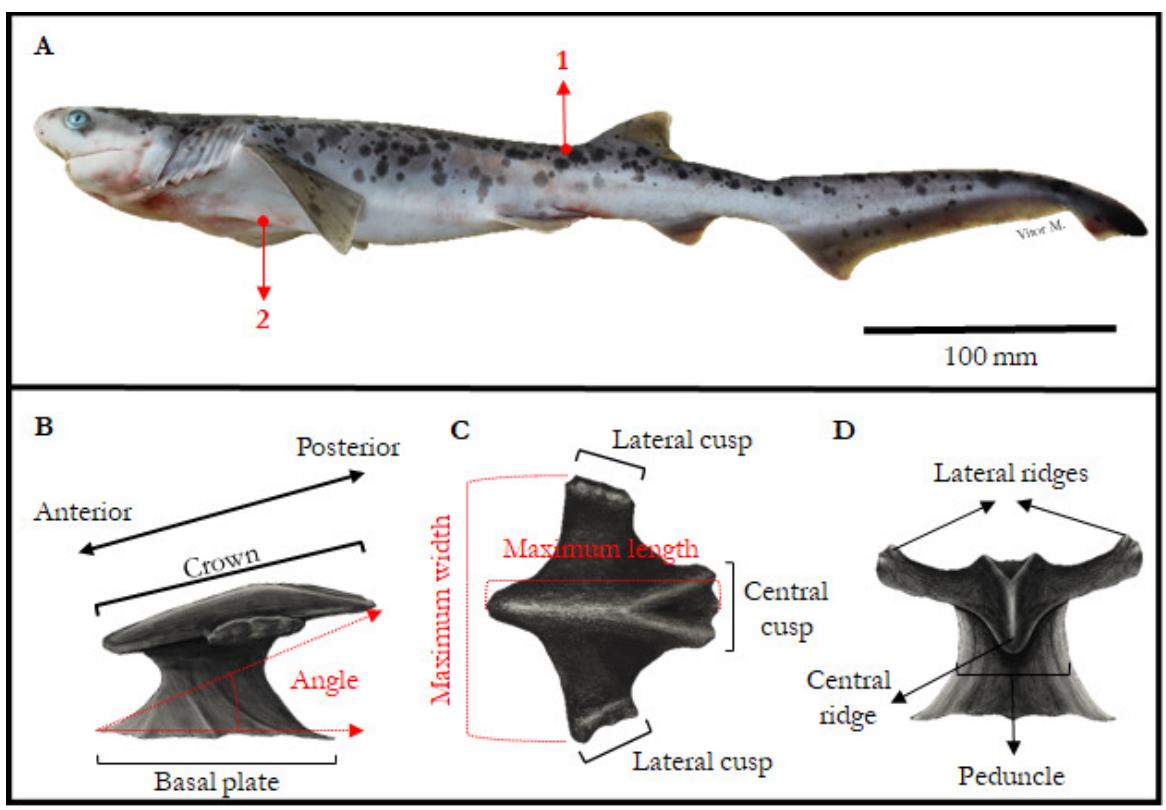

Figure 2. A) Adult specimen of Notorynchus cepedianus pointing out the two regions for skin sampling (Photo: Vitor M.): (1) dorsal region (in front of dorsal fin) and (2) ventral region (between pectoral fins) B) Lateral view of a dermal denticle; C) Dorsal view of denticle crown; D) Side view of the crown.

\subsection{Characterization of dermal denticles}

The characterization of dermal denticles was carried out considering the methodology of Reif (1982); Muñoz-Chápuli (1985); Tanaka et al. (2002); Branco (2009); Gilligan and Otway (2011); Marshall (2011); and Ankhelyi et al. (2018). The following characters were considered: (1) denticle distribution type (overlapping, abutting or separate), (2) density of dermal denticles per square millimeter (DD/mm²), (3) shape of the crown, (4) size (maximum length and width of the crown) (Figure 2C), (5) angle that forms the base with the peduncle of the denticle (Figure 2B), (6) presence and shape of the peduncle, (7) presence, shape and number of crests and cusps on the crown, (8) visibility and shape of the junction between the peduncle and the crown and (9) presence of microrelief (small grooves on the surface of the crown) (Figure 2).

\subsection{Statistical analysis}

The summary statistics: mean, standard deviation (SD), minimum value (Min. value), maximum value (Max. value), skewness and kurtosis were reported. The Shapiro-Wilk test (Shapiro and Wilk, 1965) was performed to assess the normality distribution of each trait, followed by an exploratory data analysis to determine potentially useful variables afterwards in comparative studies. To assess which traits are relevant according to the individual classification categories, a Principal Component Analysis (PCA) and the Cluster Analysis were performed by the "Stats" R package (R Core Team, 2021) and "Cluster" R package version 2.1.2 (Maechler et al., 2021), considering the average Euclidean distance criterion between pairs of observations. In addition, a Spearman Linear Correlation analysis to determine significant association $(p<0.05)$ presence between traits, according to the following formula:

$$
\rho=1-\frac{6}{n\left(n^{2}-1\right)} \sum_{i} d_{i}^{2}
$$


Where $\rho$ corresponds to the value of Spearman correlation coefficient, $d_{i}$ means the differences between pairs of values within ranking (with $i=1, \ldots, n$ ) and $n$ represents the number of observations. Additionally, the linear regression coefficients for each pair of variables were calculated according to the following expression, using the "mblm" R package (Komsta, 2019):

$$
Y_{i}=m \cdot X_{i}+b+\varepsilon_{i}
$$

Where, $Y_{i}$ represents the $i$-th observation of the independent variable (with $i=1, \ldots, n$ ), $X_{i}$ corresponds to the $i$-th observation of the independent variable, $m$ represents the linear regression coefficient or calculated slope, $b$ corresponds to the intercept and $\varepsilon_{i}$ means the random residual error.

Furthermore, in order to assess significant differences, the following analysis were performed (1) within sex and body region categories, the Wilcoxon signed-rank test (Wilcoxon, 1945) or T-test (Gosset, 1908) and (2) within life-stage, Kruskal-Wallis (Kruskal and Wallis, 1952) or Analysis of Variance (Fisher, 1939) followed by the post hoc Dunn's Test (Dunnett, 1955) or Tukey's test (Tukey, 1949) for multiple comparison respectively, depending on the distribution nature of each trait.

\section{Results and Discussion}

\subsection{Dermal denticles}

The results showed similarities in morphological aspects of dermal denticles between both body regions, life-stage and both sexes. In particular, dermal denticles had reported separate distribution, low average density, short and thickened peduncle, cross-shaped crown with three cusps (one at central region and two lateral cusps) and a pronounced central ridge that runs the entire crown length. Micro-relief was not observed (Figure 3 and Figure 4). Similar results have been reported by Raschi and Elsom (1986); Castro (2011); and Chernova and Vorob'eva (2010). Also, these authors observed the presence of a crown with a centrally-located and two laterally-located cusps in dermal denticles of this specie.

Our results reported differences in shape and size traits between body regions and life-stage. However, no differences were reported by sex categories. The differences that were found are: (1) The crown is shaped like a cross, apparently as the individual grows older, this shape is gradually lost and is not very defined like that of neonates and juveniles, this may be due to wear on the edges of the crown. This can be seen in both the dorsal and ventral regions. (2) The length of the cusps of the crown varied according to the life stage of each individual. It was also observed that the lateral cusps are larger in the dorsal region than in the ventral region. In particular, adult individuals reported that in the dorsal region, the tips of the lateral cusps are blunt and in some cases are lost, as the individuals grow. Additionally, it was observed that the width of the central cusp is thinner and apparently as the individual grows it can be observed that it becomes wider, it becomes more noticeable in those of the ventral region (Figure 3 and Figure 4). Overall, the presence of a crown with three cusps and a central ridge that runs the entire length of the crown in $N$. cepedianus dermal denticles, seems to be a morphological character shared with other species of Hexanchidae family as Heptranchias perlo (Castro, 2011; Dillon et al., 2017), Hexanchus griseus (Castro, 2011; Rangel et al., 2019), and Hexanchus nakamurai (Castro, 2011; Ebert et al., 2013). 

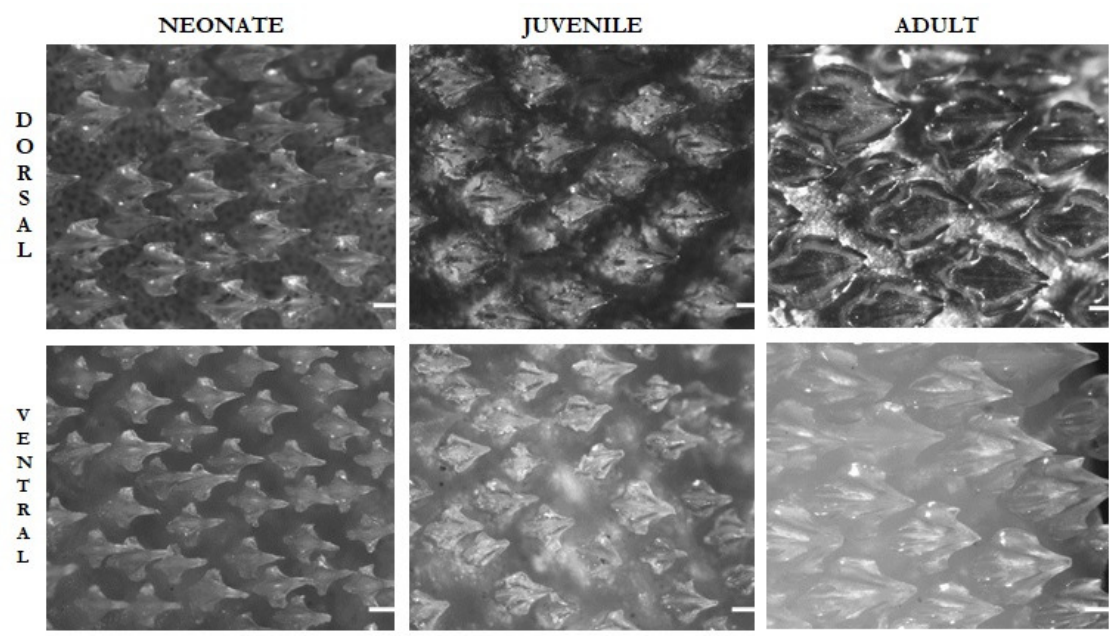

Figure 3. Photographs of dermal denticles from female specimens of Notorynchus cepedianus of dorsal and ventral region and three life-stage (scale bar $=0.1 \mathrm{~mm}$ ).

Differences were found in the morphological structure according to the region of the body and the stage of life. Similarly, with the works of Raschi and Elsom (1986); Raschi and Tabit (1992); Ankhelyi et al. (2018); and Rangel et al. (2019) who worked on different species of elasmobranchs and confirmed that the denticles of different areas of the body varied widely in size, shape and spacing. They mention the importance of comparative studies of denticles, considering different body regions and life stages. Therefore, the differences in the morphology of the dermal denticles may be related to specific functions that they fulfil in each part of the shark's body throughout its life cycle, as mentioned by Raschi and Elsom (1986); Dillon et al. (2017); and Rangel et al. (2019).
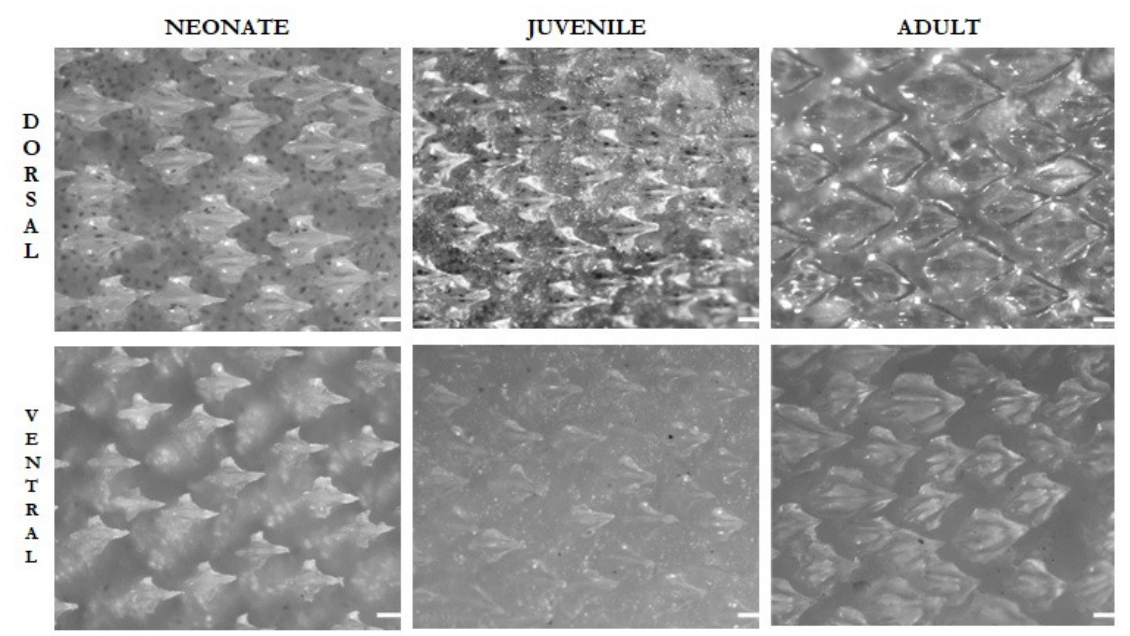

Figure 4. Photographs of the dermal denticles from male specimens of Notorynchus cepedianus of dorsal and ventral region and the three life-stage (scale bar $=0.1 \mathrm{~mm}$ ). 
There are several types of denticles that can fulfil different functions, which are related to hydrodynamics, resistance to rock abrasion, defence, luminescence, silent movements and even food acquisition (Raschi and Elsom, 1986; Raschi and Tabit, 1992; Smith and Heemstra, 1986; Dillon et al., 2017). Considering our results in both regions of the body and in different life stages of the dermal denticles of $N$. cepedianus, these resemble the results found in Reif $(1982,1985 \mathrm{~b})$ who mentions that species of the Hexanchidae family have denticles that have a generalized function and are characterized by presenting a morphology with long ridges and developed lateral ones. Raschi and Tabit (1992) observe that the denticles of species with generalized functions can present true crowns, with a plate shape and longitudinal ridges up to spine-shaped or cross-shaped crowns, as is the case of $N$. cepedianus. Dillon et al. (2017) mention that the demersal species of the Hexanchidae family usually present large, thick and ridgeless denticles with a rounded cusp that fulfil the function of resistance to abrasion or lanceolate denticles with ridges that have functions of resistance to abrasion and generalized functions. Ferón and Botella (2017) mention that slow open water species that are commonly associated with the continental shelf, species and demersal species, found in sandy and muddy substrates that belong to the Hexanchidae family, present differences between the denticles of the dorsal region and ventral that are characteristic with the morphotype that encompass species with denticles that have generalized functions.

It can be observed in Table 2 that the denticles of $N$. cepedianus have a small to medium size $\left(0.28 \mathrm{~mm}\right.$ to $0.63 \mathrm{~mm}$ in length) and a low average density $\left(4 \mathrm{DD} / \mathrm{mm}^{2}\right.$ to $\left.16 \mathrm{DD} / \mathrm{mm}^{2}\right)$. Our results partially agree with that observed by Muñoz-Chápuli (1985), who observed that the species that were within Group 2 had large denticles $(0.5 \mathrm{~mm}$ to $1.2 \mathrm{~mm}$ in length) and a low density ( $2 \mathrm{DD} / \mathrm{mm}^{2}$ to $6 \mathrm{DD} / \mathrm{mm}^{2}$ ). This may be due to the fact that Muñoz-Chápuli (1985) observed denticles in the lateral region of the organisms, and we observed the dorsal and ventral regions. The results of the density of the denticles of $N$. cepedianus (only two samples) found by Raschi and Tabit (1992) are within the range that we obtained $\left(9.24 \mathrm{DD} / \mathrm{mm}^{2}\right)$, which is characterized by species that present a generalized function. The variation in sizes (length of the crown) that denticles present in their different stages of life is due to the fact that, like their teeth, they do not increase in size once they are fully formed, but are continually replaced by new ones formed and slightly larger throughout their life. That is why there is variation in the shape and size of the denticles (Smith and Heemstra, 1986), which can also affect the density of denticles in the skin of individuals.

\section{Characters comparison}

Summary statistic for central tendency indices (average), dispersion (standard deviation (SD), minimum and maximum values), shape (skewness and kurtosis) and the results of the Shapiro-Wilk normality test for traits (length, width, density and angle) were reported in Table 2. Moreover, only angle trait reported Gaussian distribution $(p=0.0677)$.

Table 2. Summary statistics for traits length, width, density and angle of dermal denticles from Notorynchus cepedianus. Sample number ( $n$ ) and standard deviation (SD).

\begin{tabular}{ccccccccc}
\hline Variable & $\boldsymbol{n}$ & Average & SD & Min. value & Max. value & Skewness & Kurtosis & $\begin{array}{c}\text { Shapiro-Wilk } \\
(\boldsymbol{p} \text {-value })\end{array}$ \\
\hline Lenght & 76 & 0.40 & 0.08 & 0.28 & 0.63 & 0.68 & 0.05 & $0.93\left(5 \times 10^{-4}\right)$ \\
Width & 76 & 0.28 & 0.05 & 0.21 & 0.45 & 1.31 & 1.76 & $0.89(<0.001)$ \\
Density & 76 & 9.24 & 2.69 & 4 & 16 & 0.46 & -0.54 & $0.96(0.0166)$ \\
Angle & 76 & 30.49 & 2.31 & 23.79 & 35.29 & -0.46 & 0.08 & $0.97(0.0677)$ \\
\hline
\end{tabular}

Universitas Scientiarum Vol. 26(3):261-279 
In particular, the PCA results have identified four components (Table 3) and traits involved in each of them. Thus, components 1 (PC1) and 2 (PC2) together explain $87.6 \%$ of whole observed variance and also suggest a low separation between characteristics of dermal denticles from dorsal and ventral region (Figure 5). These results are consistent with previously work carried out by Reif (1985b) and Raschi and Tabit (1992), who reported presence of quantitative morphological features useful for morphotypes description. Consequently, loading values of each trait on each component (Table 3) show that the traits most correlated with PC1 and PC3 are length, width, density and angle; with PC2, are length, width and angle; and with PC4, length and width, respectively. Moreover, about PC1, length and width have the same loading value (0.59), contrary to density, which has a negative value $(-0.53)$. On the other hand, angle has a lower loading and negative value $(-0.17)$ for this component. In second place, about PC2, the most relevant trait is angle (0.97), followed by width (0.17) and length (0.16). Then, about PC3, the most relevant trait was density (0.85), followed by width (0.37), length (0.35) and angle ( -0.17$)$. Finally, the PC4 was correlated in a similar magnitude but inversely with length $(0.71)$ and width $(-0.70)$, respectively.

Furthermore, the cluster analysis reported presence of two large groups between denticles obtained from dorsal and ventral body region, regardless of life-stage and sex of the individuals (Figure 6). Similar results have been reported by Reif (1985a,b); Motta et al. (2012); Díez et al. (2015); and Ferón and Botella (2017) pointing out significant differences between denticles present in both areas, which are exposed to friction against the water. Otherwise, a small group of records from four individuals (red and blue divisions) presented differences compared with both groups clearly identified. Actually, red group was made up of two females, one of them an adult female and the other a juvenile, who reported the highest degree of morphological differentiation of their dermal denticles in comparison with the rest of the groups. Finally, the blue group was made up of a juvenile female and a neonate male.

In addition, the correlation and linear regression to explore the relationship between traits have considered non-parametric methods according to the normality test results of each one, which are reported in Table 4. The non-parametric linear regression coefficients reported significant $(p<0.05)$ values. Thus, length and width traits reported the highest and positive value $(m=$ $0.5056, p=3.6 \times 10^{-14}$ and $b=0.067$ ) of linear relationship, (Figure 7) followed by angle and density ( $m=0.1269, p=0.00252)$. In contrast, the rest of combinations have reported negative linear relationships, in which density and width reported the largest negative value $(m=-35.417$, $\left.p=3.63 \times 10^{-13}\right)$, followed by length and density $\left(m=-22.222, p=3.324 \times 10^{-13}\right)$, width and angle $(m=-3.591, p=0.0081)$ and length and angle $(m=-3.096, p=0.0044)$, respectively.

Besides, Spearman's correlation analysis reported a high positive correlation between width and length traits $\left(\rho=0.9251, p<2.2 \times 10^{-16}\right)$. Likewise, consistent results from previous work by Sullivan and Regan (2011) reported high linear correlation $(\rho=0.84)$ between these

Table 3. Traits loading values by each principal component (PC).

\begin{tabular}{ccccc}
\hline Variables & PC1 & PC2 & PC3 & PC4 \\
\hline Length & 0.59 & 0.16 & 0.35 & 0.71 \\
Width & 0.59 & 0.17 & 0.37 & -0.70 \\
Density & -0.53 & - & 0.85 & - \\
Angle & -0.17 & 0.97 & -0.17 & - \\
\hline
\end{tabular}




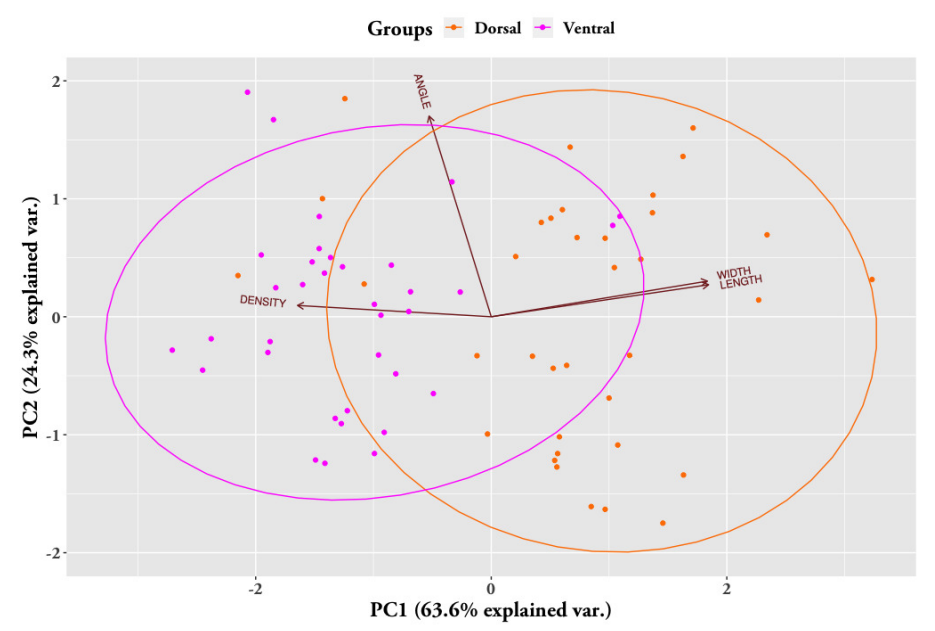

Figure 5. Biplot of principal components analysis considering body region where which length, width, angle and density of dermal denticles were measured. Ellipses containing the $80 \%$ of observations according to each body region.

variables in Scyliorhinus canicula. Hence, these results point out that both variables are potentially predictive of each other in those species. Then, moderate and negative values for density and length $\left(\rho=-0.6603, p=8.6 \times 10^{-11}\right)$ and density and width $(\rho=-0.6780, p=1.7 e-11)$ were reported. On the contrary, non-significant correlation values were reported between angle and length $(\rho=-0.0758, p=0.5151)$, angle and width $(\rho=-0.1091, p=0.348)$ and angle and density ( $\rho=0.1814, p=0.167)$, respectively. Overall, these results are potentially useful in further studies that consider predictive modelling (e.g. multiple linear regression or generalized linear models) in which correlation values over 0.9 between two variables allow to retain only one of them to represent both in a linear model, avoiding multicollinearity (Chen, 2012; Tabachnick and Fidell, 2014).

Moreover, significant differences within sex, life-stage and body region for each trait were reported in Table 5. Firstly, for sex category significant differences were reported only for length trait ( $W=794, p=0.4055)$, consistently with previous results reported by Grasa (2018) in Deania calcea. In contrast, width $(W=853.5, p=0.1451)$, density $(W=692, p=0.8209)$ and angle $(t=-1.1077, p=0.2718)$, did not. In second place, considering the life-stage and comparing (i) neonate and juvenile individuals, significant differences were reported only for angle trait $(D=$ $1.8429, p=0.0073)$. On the contrary, length $(Z=-0.0826, p=0.9999)$, width $(Z=1.0673$, $p=0.8576)$, density $(K-W$ chi-squared $=2.4904, p=0.2879)$. In third place, comparing (ii) neonate and adult individuals, significant differences were reported for length $(Z=2.5639, p=$ $0.0310)$ and width $(Z=3.5528, p=0.0011)$. However, for density $(K$ - $W$ chi-squared $=2.4904$, $p=0.2879)$ and angle $(D=0.7182, p=0.6441)$, non-significant differences were reported. In

Table 4. Linear regression (above diagonal) and correlation (below diagonal) coefficients. Reported $p$-values in parentheses.

\begin{tabular}{ccccc}
\hline Variable & Length & Width & Density & Angle \\
\hline Length & - & $0.5059\left(3.6 \times 10^{-14}\right)$ & $-22.222\left(3.324 \times 10^{-13}\right)$ & $-3.096(0.0044)$ \\
Width & $0.9251\left(<2.2 \times 10^{-16}\right)$ & - & $-35.417\left(3.63 \times 10^{-13}\right)$ & $-3.591(0.0081)$ \\
Density & $-0.6603\left(8.6 \times 10^{-11}\right)$ & $-0.6780\left(1.7 \times 10^{-11}\right)$ & - & $0.1269(0.00252)$ \\
Angle & $-0.0758(0.5151)$ & $-0.1091(0.348)$ & $0.1814(0.167)$ & - \\
\hline
\end{tabular}


Cluster Analysis

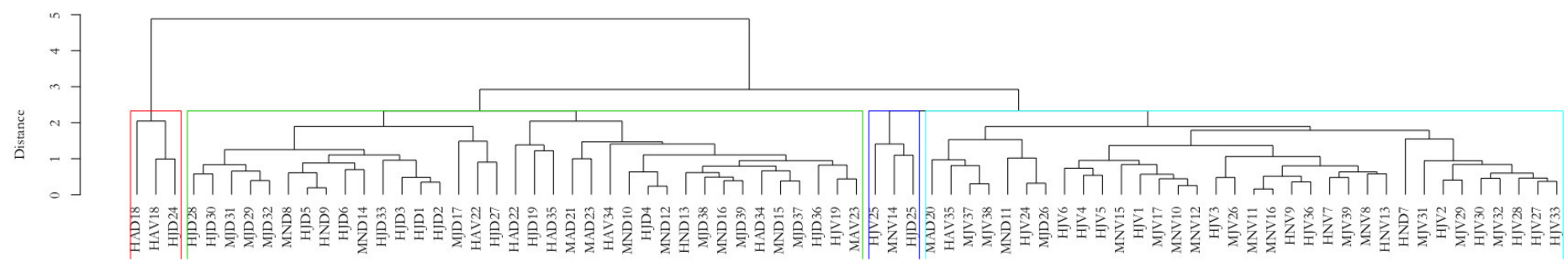

Figure 6. Cluster dendrogram between dermal denticles of $N$. cepedianus individuals. Colored separations point main groups considering morphological similarities.

fourth place, comparing (iii) juvenile and adult individuals, significant differences were found for length $(Z=2.9432, p=0.0097)$ and width $(W=3.0997, p=0.0058)$, respectively. On the other hand, non-significant differences were reported in density $(K$ - $W$ chi-squared $=2.4904$, $p=0.2879)$ and angle $(D=-1.1247, p=0.2630)$ traits. Finally, considering body regions where dermal denticles were assessed, significant differences between dorsal and ventral region were reported for length $\left(W=1300, p=1.783 \times 10^{-9}\right)$, consistently with previous results reported by Grasa, (2018) in Deania calcea, width $\left(W=1266.5, p=1.362 \times 10^{-8}\right)$ and density $\left(W=267.5, p=2.029 \times 10^{-6}\right)$ traits. In contrast, only angle has reported non-significant differences $(t=-1.765, p=0.0818)$ between both body regions. Overall, our results are consistent with descriptive works by Gilligan and Otway (2011), and Sullivan and Regan (2011), where distinct patterns of differentiation in width and length traits across body region work as identification criteria.

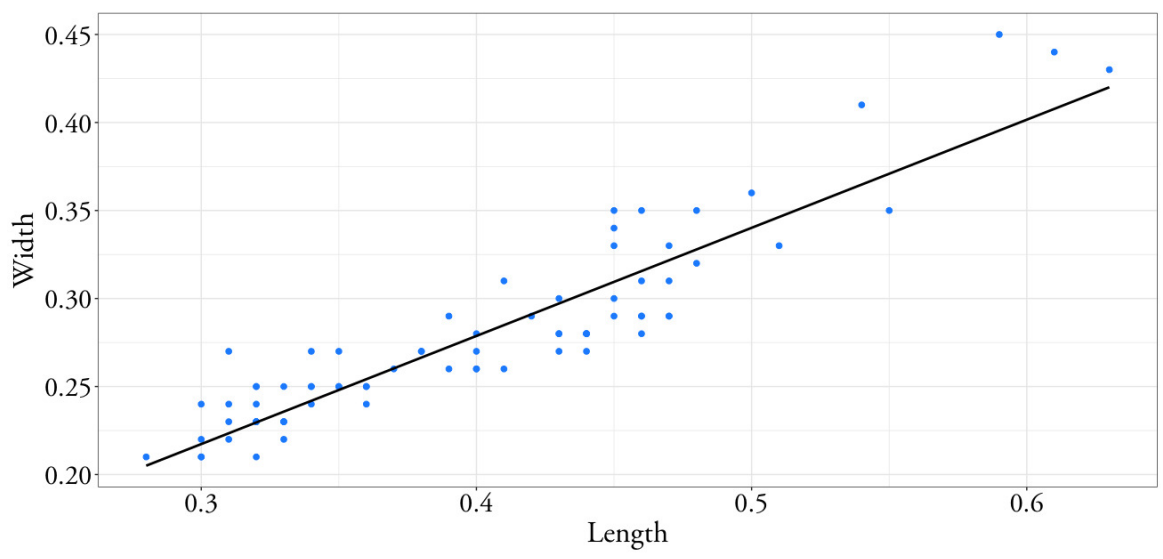

Figure 7. Relationship between width and length traits of dermal denticles in Notorynchus cepedianus individuals. 
Table 5. Reported $p$-values for multiple comparisons tests between sex, life-stage and body regions categories and assessed traits.

\begin{tabular}{ccccc}
\hline Comparisons & Length & Width & Density & Angle \\
\hline Female-Male & 0.4055 & 0.1451 & 0.8209 & 0.2718 \\
Neonate-Juvenile & 0.9999 & 0.8576 & 0.2879 & $0.0073^{*}$ \\
Neonate-Adult & $0.0310^{*}$ & $0.0011^{*}$ & 0.2879 & 0.6441 \\
Juvenile-Adult & $0.0097 *$ & $0.0058^{*}$ & 0.2879 & 0.2630 \\
Dorsal-Ventral & $1.783 \times 10^{-9 *}$ & $1.362 \times 10^{-8 *}$ & $2.029 \times 10^{-6 *}$ & 0.0818 \\
\hline \multicolumn{5}{c}{$*$ mean significant differences. } \\
\hline
\end{tabular}

\section{Conclusions}

In summary, the present study reported the presence of relevant morphological traits present in $N$. cepedianus dermal denticles, which are correlated (e.g. length and width) and specific for life-stage and body region. In contrast, sexual dimorphism in dermal denticles traits was not found for this species.

The dermal denticles of N. cepedianus are usually distributed in the body in a separate way, low density average, presence of a short and thickened peduncle, a cross-shaped crown with three cusps and a pronounced central ridge that runs the entire length of the crown, the presence of microrelief is not observed in these structures. Moreover, these characteristics are common between individuals independently of body region and life-stage. Thus, a dermal denticle with crown with three cusps and a central cusp more pronounced seems to be the shared morphological trait among the four species within Hexanchidae family. It is worth mentioning that the morphological characteristics of the denticles of this species are related to their fulfilment of generalized functions.

\section{Acknowledgements}

This work was partially funded by Fondo Semilla 2018 (RDN ${ }^{\circ}$ 01-DGIDI-CIENTÍFICA-2018/ $\mathrm{CRN}^{\circ}$ 002-2018-PRO5) of the Universidad Científica del Sur. We thank the Laboratorio de Investigación and Laboratorio de Ecología Marina of the Universidad Científica del Sur for allowing us use laboratories, equipment and material (Aponte H, Indacochea A, López E, Obeso H, Caldas F.). We also thank the Banco de Germoplasma of the Instituto del Mar del Perú IMARPE (Aguilar C, Tenorio C, Hernández H, Sánchez PPA, Arakaki N, Aguirre M.) for the provided support in the laboratory and the stereoscope usage. Furthermore, we want to thank to the students who collected some samples (Kohatsu S, Valderrama M, Indacochea A, Vitor M.) and processed skin samples (Gonzales G, Arévalo A.). We also want to thank Vitor M. for $N$. cepedianus picture provided and Laguna L. for drawing the illustrations of the denticles. Sergio Ramírez-Amaro is funded by a post-doctoral contract from the regional government of the Balearic Islands, co-funded by the European Social Fund 2014-2020. Finally, this study is part of the CRN 002-20018-PRO5 project and the MSc dissertation project of Keny Kanagusuku. 


\section{Conflict of interest}

The authors certify that they have no affiliations with or involvement in any organization or entity with any financial interest (such as honoraria; educational grants; participation in speakers membership, employment, consultancies, stock ownership, or other equity interest; and expert testimony or patent arrangements), or non (such as personal or professional relationships, affiliations, knowledge or beliefs) in the subject matter or materials discussed in this manuscript. Potential conflicts of interest related to individual authors' commitments. Potential conflicts of interest related to commitments of editors, journal staff, or reviewers.

\section{References}

ACOREMA (Áreas Costeras y Recursos Marinos). Los tiburones de la provincia de Pisco, Ica, Perú. 2014.

http://www.acorema.org.pe/documentos/Los_Tiburones_de_la_Provincia_de_ Pisco-ACOREMA-2014.pdf

Ankhelyi MV, Wainwright DK, Lauder GV. Diversity of dermal denticle structure in sharks: Skin surface roughness and three-dimensional morphology, Journal of morphology, 279: 1132-1154, 2018.

doi: $10.1002 /$ jmor.20836

Branco CH. Dentículos dérmicos de tubarões da Costa Portuguesa: a sua utilização para identificação das diferentes espécies. Doctoral dissertation, Universidad de Lisboa, Portugal. 2009. https://core.ac.uk/download/pdf/12421744.pdf

Castro JI. The sharks of North America. Oxford University Press. New York, 613 pp, 2011.

Chen G. A simple way to deal with multicollinearity, Journal of Applied Statistics, 39(9): 1893-1909, 2012.

Chernova OF \& Vorob'eva EI. Polymorphism of the surface sculpture of placoid scales of sharks (Selachimorpha, Elasmobranchii). In Doklady Biological Sciences. MAIK Nauka/Interperiodica, 446(1): 316-319, 2012. doi: $10.1134 / \mathrm{S} 0012496612050067$

Chirichigno N, Vélez J. Clave para identificar los peces marinos del Perú, Instituto del Mar del Perú -IMARPE, Callao, Perú. 2: 496, 1998.

http://biblioimarpe.imarpe.gob.pe/handle/123456789/3327

Chirichigno N, Cornejo M. Catálogo comentado de los peces marinos del Perú. Instituto del Mar del Perú - IMARPE, Callao. 2001.

Compagno L, Dando M, Fowler S. Guía de campo de los tiburones del mundo, Omega, 2006.

Compagno LJV. Notorynchus cepedianus. The IUCN Red List of Threatened Species 2009: e.T39324A10200310, 2009.

https://www.iucnredlist.org/species/39324/10200310

Deynat PP \& Séret B. Le revêtement cutané des raies (Chondrichthyes, Elasmobranchii, Batoidea). I-Morphologie et arrangement des denticules cutanés. Annales des sciences naturelles, Zoologie et biologie animale, 17(2): 65-83, 1996.

doi: 10.1016/S0003-4339(99)80004-5 
Díez G, Soto M, Blancos J. Biological characterization of the skin of shortfin mako shark Isurus oxyrinchus and preliminary study of the hydrodynamic behaviour through computational fluid dynamics, Journal of Fish Biology, 87: 123-137, 2015.

doi: $10.1111 / \mathrm{jfb} .12705$

Dillon EM, Norris RD, Dea AO. Dermal denticles as a tool to reconstruct shark communities, Marine Ecology Progress Series, 566: 117-134, 2017.

doi: $10.3354 /$ meps 12018

Dillon EM, Lafferty KD, McCauley DJ, Bradley D, Norris RD, Caselle JE, DiRenzo GV, Gardner JPA, O'Dea, A. Dermal denticle assemblages in coral reef sediments correlate with conventional shark surveys, Methods in Ecology and Evolution, 11(3): 362-375, 2020.

doi: 10.1111/2041-210X.13346

Dunnett C. A multiple comparison procedure for comparing several treatments with a control, Journal of the American Statistical Association, 50(272): 1096-1121, 1955. doi: 10.1080/01621459.1955.10501294

Ebert DA. Biology of the sevengill shark Notorynchus cepedianus (Peron, 1807) in the temperate coastal waters of southern Africa. South African Journal of Marine Science, 17(1): 93-103, 1996.

doi: $10.2989 / 025776196784158545$

Ebert DA, White WT, Ho HC. Redescription of Hexanchus nakamurai Teng 1962, (Chondrichthyes: Hexanchiformes: Hexanchidae), with designation of a neotype, Zootaxa, 3752(1): 20, 2013.

doi: 10.11646/zootaxa.3752.1.4

Ferrón H, Pla C, Martínez-Pérez C, Escudero-Mozo MJ, Botella H. Morphometric discriminant analysis of isolated chondrichthyan scales for palaeoecological inferences: the Middle Triassic of the Iberian Chain (Spain) as a case of study. 2014.

Ferrón HG, Botella H. Squamation and ecology of thelodonts, PloS one, 12(2): e0172781, 2017.

Ferrón HG, Paredes-Aliaga MV, Martínez-Pérez C, Botella H. Bioluminescent-like squamation in the galeomorph shark Apristurus ampliceps (Chondrichthyes: Elasmobranchii), Contributions to Zoology, 87(3): 187-196, 2018.

doi: $10.1163 / 1875986608703004$

Ferrón HG, Herraiz, JL, Botella H, Martinez-Perez C. Pre-Messinian ecological diversity of Mediterranean sharks revealed by the study of their dermal denticles. [Diversidad ecologica pre-Messiniense en tiburones del Mediterraneo según un estudio de sus denticulos dermicos], Spanish Journal of Palaeontology, 34(2): 289-298, 2019.

https://ojs.uv.es/index.php/sjpalaeontology/article/view/16118

Finucci B, Barnett A, Cheok J, Cotton CF, Kulka DW, Neat FC, Pacoureau N, Rigby CL, Tanaka S, Walker TI. Notorynchus cepedianus. The IUCN Red List of Threatened Species 2020: e.T39324A2896914. 2020.

doi: 10.2305/IUCN.UK.2020-3.RLTS.T39324A2896914.en

Fisher R. The comparison of samples with possibly unequal variances, Annals of Eugenics, 9(2): 174-180, 1939

doi: 10.1111/j.1469-1809.1939.tb02205.x 
Gilligan JJ, Otway NM. Comparison of dorsal and pectoral fin denticles for grey nurse, great white, and six whaler sharks from east Australian waters, In Journal and Proceedings of the Royal Society of New South Wales, 144 (3-4): 66-82, 2011.

https://royalsoc.org.au/images/pdf/journal/144_Nos_441_442.pdf\#page=20

Gonzalez-Pestana A, Kouri C, Velez-Zuazo X. Shark fisheries in the Southeast Pacific: A 61-year analysis from Peru. F1000Research, 3, 2014.

doi: 10.12688/f1000research.4412.2

Gosset W. The probable error of a mean, Biometrika, 6(1): 1-25, 1908.

doi: 10.1093/biomet/6.1.1

Grasa I. Caracterización morfológica y molecular de la especie Deania calcea (Lowe, 1839), Master dissertation, Universidade da Coruña, España. 2018. https://core.ac.uk/download/pdf/12421744.pdf

IMARPE (Instituto del Mar del Perú). Guía para la determinación de tiburones de importancia comercial en el Perú. Instituto del Mar del Perú-IMARPE, Serie de Divulgación Científica, 1(2): 80, 2015.

http://biblioimarpe.imarpe.gob.pe/handle/123456789/3007

Jolie M. Some implications of the acceptance of a delamination principle. In Orvig T, editor. Current problems of lower vertebrate phylogeny, Stockholm: Almqvist and Wiskell, 89-108, 1968.

Kemp NE. Integumentary system and teeth. In W. C. Hamlett (ed.), Sharks, Skates and Rays. John Hopkins University Press, Baltimore, Maryland, 43-68, 1999.

Komsta L. Package "mblm”, 2019.

https://cran.r-project.org/web/packages/mblm/mblm.pdf

Kriwet J, Benton MJ. Neoselachian (Chondrichthyes, Elasmobranchii) diversity across the cretaceous-tertiary boundary. Palaeogeography, Palaeoclimatology, Palaeoecology, 214: 181-194, 2004.

doi: 10.1016/j.palaeo.2004.02.049

Kriwet J, Kiessling W, Klug S. Diversification trajectories and evolutionary life-history traits in early sharks and batoids. Proceedings of the Royal Society B: Biological Sciences, 276: 945-951, 2008.

doi: $10.1098 / \mathrm{rspb} .2008 .1441$

Kruskal W, Wallis W. Use of rank in one-criterion variance analysis, Journal of the American Statistical Association, 48: 907-911, 1952.

doi: 10.1007/978-0-387-32833-1

Last PR, Stevens JD. Sharks and Rays of Australia. Melbourne, CSIRO Division of Fisheries, 513p, 1994.

Maechler M, Rousseeuw P, Struyf A, Hubert M, Hornik K, Studer M, Roudier P. Package "Cluster". 2021.

https://cran.r-project.org/web/packages/cluster/cluster.pdf 
Marshall LJ. The fin blue line: Quantifying fishing mortality using shark fin morphology, Doctoral dissertation, University of Tasmania, Australia. 2011.

https://eprints.utas.edu.au/10721/

Motta P, Habegger ML, Lang A, Hueter R, Davis J. Scale morphology and flexibility in the shortfin mako Isurus oxyrinchus and the blacktip shark Carcharhinus limbatus. Journal of morphology, 273: 1096-1110, 2012.

doi: $10.1002 /$ jmor.20047

Muñoz-Chápuli R. Sobre la clasificación tipológica del esqueleto dérmico de escualos (Chondrichtyes), Miscelània zoológica, 9: 396-400, 1985.

https://www.raco.cat/index.php/Mzoologica/article/download/92036/144953

PRODUCE (Ministerio de la Producción). Plan de Acción Nacional para la Conservación y Ordenamiento de Tiburones, Rayas y Especies Afines en el Perú (PAN Tiburón-Perú). Decreto Supremo № 002-2014. Lima, Perú, 2014.

http://www2.produce.gob.pe/dispositivos/publicaciones/rm295-2013-produce.pdf

Rangel BdS, Amorim AF, Kfoury Jr. JR, Rici REG. Microstructural morphology of dermal and oral denticles of the sharpnose sevengill shark Heptranchias perlo (Elasmobranchii: Hexanchidae), a deep-water species, Microscopy Research \& Technique, 82: 1243-1248, 2019.

doi: $10.1002 /$ jemt.23273

Raschi W, Elsom J. Comments on the structure and development of the drag reduction type placoid scale. In Indo-Pacific Fish Biology: Proceedings of the Second International Conference on Indo-Pacific Fishes. (Eds T. Uyeno, R. Arai, T. Taniuchi and K. Matsuura.), 408-424, 1986.

Raschi W, Tabit C. Functional aspects of Placoid Scales: A review and update. Marine and Freshwater Research, 43(1): 123, 1992.

doi: $10.1071 / \mathrm{mf} 9920123$

R Core Team. R: A language and environment for statistical computing. R Foundation for Statistical Computing, Vienna, Austria. 2021

https://www.R-project.org/

Reif WE. Protective and hydrodynamic function of the dermal skeleton of elasmobranchs, Neues Jahrbuch für Geologie und Paläontologie-Abhandlungen, 157: 133-41, 1978.

Reif WE. Evolution of dermal skeleton and dentition in vertebrates. In Evolutionary biology. Springer US. 287-368, 1982.

doi: 10.1007/978-1-4615-6968-8_7

Reif WE, Dinkelacker A. Hydrodynamics of the squamation in fast swimming sharks. Neues Jahrbuch für Geologie und Paläontologie-Abhandlungen, 184-187, 1982.

Reif WE. Squamation and ecology of sharks. Cour Forschungsinstitut Senckenb Band 78, Schweizerbart Science Publisher, Stuttgart. 1985a.

Reif WE. Functions of Scales and Photophores in Mesopelagic Luminescent Sharks. Acta Zoologica, 66(2), 111-118, 1985b.

doi: 10.1111/j.1463-6395.1985.tb00829.x 
Romero M, Alcántara P, Verde K. Guía de campo para la determinación de tiburones en la pesca artesanal del Perú. Instituto del Mar del Perú-IMARPE, Perú. 2015. http://biblioimarpe.imarpe.gob.pe/handle/123456789/3197

Romero M. Manual para de identificación de troncos de tiburones de importancia comercial en el Perú. Instituto del Mar del Perú-IMARPE, Perú. 16, 2018. http://biblioimarpe.imarpe.gob.pe/handle/123456789/3305

Schaeffer B. The dermal skeleton in fishes. In Andrews SM, Miles RS, Walker AD, editors. Problems in vertebrate evolution. London: Academic Press, 25-52, 1977.

Shapiro S, Wilk M. An analysis of variance test for nomality (complete samples), Biometrika, 52: 591-611, 1965. doi: $10.2307 / 2333709$

Smith MM, Heemstra PC. Class Chondrichthyes, Smiths' Sea Fishes, 39-147, 1986. doi: 10.1007/978-3-642-82858-4_12

Southall EJ, Sims DW. Shark skin: a function in feeding. Proceedings of the Royal Society of London. Series B: Biological Sciences, 270(suppl_1): S47-S49, 2003.

Sullivan T, Regan F. The characterization, replication and testing of dermal denticles of Scyliorhinus canicula for physical mechanism of biofouling prevention, Bioinspiration \& Biomimetics, 6: 1-11, 2011. doi: $10.1088 / 1748-3182 / 6 / 4 / 046001$

Tabachnick B, Fidell L. Using Multivariate Statistics. $6^{\text {th }}$ Ed. Pearson Education Limited. Edinburgh, UK. 1056 pp, 2014. https://www.pearsonhighered.com/assets/preface/0/1/3/4/0134790545.pdf

Tanaka S, Kitamura T, Nakano H. Identification of shark species by SEM observation of denticle of shark fins. Collective Volume of Scientific Papers ICCAT, 54: 1386-1394, 2002. http://www.flyingsharks.eu/literature/iccat/CV054041386.pdf

Tukey J. Comparing individual means in the analysis of variance. Biometrics, 5(2): 99-114, 1949. doi: $10.2307 / 3001913$

Valenzuela A, Bustamante C, Lamilla J. Morphological characteristics of five bycatch sharks caught by southern Chilean demersal longline fisheries. Scientia Marina, 72(2): 231-237, 2008 .

doi: $10.3989 /$ scimar.2008.72n2231

Van Dykhuizen G \& Mollet HF. Growth, age estimation and feeding of captive Sevengill Sharks, Notorynchus cepedianus, at the Monterey Bay Aquarium, Marine and Freshwater Research, 43(1): 297, 1992.

doi: $10.1071 / \mathrm{mf} 9920297$

Wen L, Weaver JC, Lauder GV. Biomimetic shark skin: design, fabrication and hydrodynamic function, Journal of Experimental Biology, 217(10): 1656-1666, 2014. doi: $10.1242 /$ jeb.097097

Wilcoxon F. Individual comparisons by ranking methods, Biometrics Bulletin, 6(1): 80-83, 1945. doi: $10.2307 / 3001968$ 
Caracterización morfológica de los dentículos dérmicos del tiburón de siete agallas Notorynchus cepedianus (Elasmobranchii: Hexanchidae)

Resumen: La piel del tiburón está cubierta de pequeñas estructuras llamadas dentículos dérmicos, cuyas funciones son tan diversas como protección, bioluminiscencia e hidrodinámica. Estas estructuras tienen una gran variedad de formas y tamaños y pueden constituir una aproximación útil como caracteres diagnósticos de los especímenes para la identificación de especies. El objetivo del presente estudio es describir la morfología de los dentículos dérmicos del tiburón de siete agallas Notorynchus cepedianus, evaluando diferencias entre estadios de vida (neonato, juvenil y adulto), sexo y región corporal (dorsal y ventral). Para lograrlo, se colectaron 39 especímenes en siete puntos de desembarque a lo largo de la costa peruana. Los dentículos dérmicos de dos regiones corporales (dorsal y ventral) se fotografiaron y midieron (longitud, ángulo y densidad) y se describieron usando un estereoscopio. Los dentículos dérmicos mostraron diferencias morfológicas significativas entre regiones corporales, así como entre estadios de desarrollo, pero no entre sexos. Las diferencias son: (1) forma de la corona: a medida que el individuo crece, se puede ver que la forma de cruz se pierde; (2) cúspides de la corona: la longitud de las cúspides varía de acuerdo con el estadio de cada individuo, y se observó también que las cúspides laterales son más largas en la región dorsal que en la ventral, y (3) la unión pedúnculo-corona: en los especímenes adultos y en ambas regiones corporales, la unión observada fue muy tenue y no tenía una forma definida. En conjunto, las variaciones reportadas en las características medidas pueden ser útiles como caracteres diagnósticos para identificar el estado de desarrollo en el cual se encuentran los especímenes desembarcados y comercializados.

Palabras Clave: descripción; Perú; escama placoidea; identificación taxonómica. 
Caracterização morfológica das dentíuclas dérmicas do Tubarão-de-sete-guelras Notorynchus cepedianus (Elasmobranchii: Hexanchidae)

Resumo: A pele dos tubarões está coberta de pequenas estruturas chamadas dentíuclas dérmicas, as quais têm diversas funções incluindo proteção, bioluminescência e hidrodinâmica. Estas estruturas apresentam uma grande variedade de formas e tamanhos pelo que servem como caracteres diagnósticos entre espécies. Esta variedade também faz delas uma boa ferramenta para identificação de espécimes. O objetivo de presente estudo foi descrever a morfologia das dentíuclas dérmicas do Tubarão-de-sete-guelras Notorynchus cepedianus, avaliando as diferenças entre estágio de vida (neonato, juvenil e adulto), sexo e região do cropo (dorsal e ventral). Para atingir o objetivo, coletamos 39 espécimes em seis pontos de pouso ao longo da costa peruana. As dentíuclas dérmicas das regiões dorsal e ventral foram fotografadas, medidas (comprimento, largura, ângulo e densidade) e descritas usando um estereoscópio. As medições das dentíuclas dérmicas mostraram diferenças morfológicas significativas entre regiões do corpo e estágios de desenvolvimento, mas não entre sexos. As diferenças foram: (1) Forma da coroa: à medida que o indivíduo cresce, pode-se observar uma perda na forma cruzada. (2) Cúspide da coroa: o comprimento das cúspides varia de acordo com o estágio de cada indivíduo, também observamos que as cúspides laterais eram maiores na região dorsal do que na região ventral. (3) Pedúnculo de união - coroa: nos espécimes adultos, independente da região do corpo, esta união era bastante ofusca e não tinha forma definida. As variações reportadas nas nossas medições podem servir como caracteres diagnósticos para identificar o estágio de desenvolvimento em que os espécimes aterrissados e comercializados são encontrados.

Palavras-chave: descrição; Peru; escala placoidea; identificação taxonômica. 
Keny Kanagusuku Biologist, graduated from the Master in Ecosystems and Aquatic Resources at the Universidad Nacional Mayor de San Marcos. She is a teacher of the Marine Biology Career at the Universidad Científica del Sur. Currently she doing her MSc dissertation on dermal denticles of sharks, as a taxonomic tool and supporting in elasmobranch research related with taxonomy, dermal denticles, malformations, embryonic development and physiology.

ORCID: 0000-0002-6896-6552

Pablo Dufflocq Is currently a $\mathrm{PhD}(\mathrm{c})$ student with a MSc. degree in Animal Science at the Universidad de Chile. He is a Doctor of Veterinary Medicine at the same university and his research interests are statistics, genetics and genomics applied to topics related with chondrichthyans.

ORCID: 0000-0003-3960-6758

Angie Sánchez-Rea Marine biologist from the Universidad Científica del Sur. She has experience in taxonomy of skates and stingrays research, using dermal covering. She has been participated in projects about trophic ecology of chondricthyans and work with breeding newborns skates in captivity.

ORCID: 0000-0001-9654-1810

Ana A Huamantinco Biologist from the Universidad Nacional Mayor de San Marcos with a $\mathrm{PhD}$ and a Msc. degree in Biological Sciences at the Universidad Federal de Rio de Janeiro.

ORCID: 0000-0001-6558-1326

Sergio Ramírez-Amaro Marine biologist from the Universidad Autónoma de Baja California, México. With a PhD in Marine Ecology from the Universitat de les Illes Balears, Spain. My research focuses on ecology and genetic of chondrichthyan fishes (sharks, skates and chimaeras). Currently, has a Post-doctoral contract in the Instituto Español de Oceanográfia.

ORCID: 0000-0002-0298-0749 